KATARZYNA JASIŃSKA

INSTITUTE OF THE POLISH LANGUAGE, KRAKÓW, POLISH ACADEMY OF SCIENCES

DARIUSZ R. PIWOWARCZYK

JAGIELLONIAN UNIVERSITY, KRAKÓW

\title{
A NOTE ON THE LATIN GRANICIES 'BORDER' AND THE -(IT)IES FORMATIONS IN THE CORPUS OF MEDIEVAL LATIN IN POLAND
}

SUMMARY: The Polish medieval Latin corpus is a specific collection of texts created during the Middle Ages in the Polish lands. The language itself had a special status as it was no longer the native language of any specific population. Consequently, it underwent changes in the lexicon to the extent that both Latin forms were transferred into Polish and the Polish ones into Latin. Such is the case with the word granicies 'border' which was transferred from the Polish word granica 'border'. The baffling thing is that the transfer itself created a word within the non-productive Latin fifth declension. The purpose of the present article is to try to explain why it was transferred to this specific type of inflection.

KEYWORDS: medieval Latin, nominal inflection

The peculiar form of granicies 'border' is attested in the corpus of the Polish medieval Latin language (du Cange also gives additional examples of its attestations outside of that corpus, cf. Du Cange 18831887). The form is basically the Polish word granica 'border' which was transferred into Latin (Weysenhoff-Brożkowa 1991: 22-23) and the transfer itself is probably not too surprising as there were other examples of this kind (cf. Weysenhoff-Brożkowa 1991 on the influence of Polish on the medieval Latin language used in Poland in general). 
What is surprising is the rendering of this form in Latin with the -ies inflection of the Latin fifth declension, a largely nonproductive type of inflection (cf. Weiss 2009: 253-255), alongside the -ia counterpart granica/granicia.

The origin of the Latin fifth declension itself has been the topic of numerous works. The two most prevalent hypotheses concerning its origin either derive it from the $*_{-} e h 1(*-\bar{e})$ inflection reconstructed for Proto-Indo-European on the basis of this type of inflection in Latin and the Baltic - $\bar{e}$-stems (Pedersen 1926, Schrijver 1991: 379-387), or denounce the connection with the Baltic formations and treat the Latin fifth declension (synchronically $-\bar{e}$-stems) as an independent creation of Latin or Italic in general (Weiss 2009: 253-255), the material from the other Italic languages being too small for a definite answer regarding the existence of this type of inflection in Sabellic (cf. Weiss 2009: 253).

In vulgar Latin and in the Romance languages the fifth declension is unproductive and is mostly replaced by the inflectional pattern of the first declension (Weiss 2009: 517). As regards the medieval Latin which continued to be used throughout the Middle Ages as the written language, this type of inflection consists mainly of the forms inherited from the Classical Latin period and there are not many new forms created within this type of inflection (cf. Rzepiela 2000: 157-158).

The Old Polish Dictionary gives the following variants of the base word granica (Stownik staropolski 483-484):

- granica

- grańca

- grenica

The oldest forms date back to the 13th century. Initially the Latin counterparts of the word granica were the forms limes and terminus (database of the Old Polish Dictionary), afterwards the Latin word granicies/granicia was used as a loan from Polish. The same Polish word was borrowed into Middle High German (Sławski 1952 v. 1 p. 339-340). Etymologically it goes back to the word gran' 'ridge' (Sławski 1952: ibidem). 
The Latin word, as a loanword from Polish (granica/grenica), appears in the material in several different variants - (WeysenhoffBrożkowa 1991: 193):

- granica (written granicza, graniza),

- grenica (written grenica, greniza),

- granicia (written garnicia, granecia, granetia, granicea, graniczia, granizia, grannicia, granygcia),

- grenicia (written grenicia, grenecia, grenicia),

- granicies, grenicies.

The attestations of both the fifth and the first declension forms date back to the 13th century - the form granica (written greniza) dates back to 1205 (according to the database of the eLexicon of the Polish Medieval Latin). The first appearance of the -ies variant dates back to 1258. The eLexicon of the Polish Medieval Latin gives the following meanings for the lemma: 'border, stipulated line dividing two estates', often also: 'border sign in the form of a mound or an incised tree', plural: 'borders, territory within the borders, vicinity'.

As to the origin of both variants, Weysenhoff-Brożkowa (1991: 2223) supposes that the word first came to be used in the form granica, directly as a calque of the Polish word. However, the creation of a new word or the transfer of one word from one language to another requires the word to conform to the phonotactic rules of the target language (in this case Latin). Thus the -ica ending was changed into -icia to conform with the rules of the Latin grammar (-tia and -cia forms are very frequent) and to prevent reading the form as /-ika/. Then, the author supposes that the form granicia changed into granicies according to the well-known alternation found in Classical Latin through which the itia nouns can be used along the their -ities variants.

For such a creation there had to exist a derivational model. In other words, speakers had to be aware of the -(it)ia/-(it)ies alternation and had to use forms with such alternation either inherited from Classical or Late Latin or created within the medieval period alone. One can wonder which other word or rule could form the model for such a transfer.

Michał Rzepiela, in his unpublished Ph. D. dissertation devoted to the nominal suffixal derivation in medieval Latin (Rzepiela 2000) lists 8 -ies derivatives which were created during the period of medieval 
Latin used in Poland: acuties 'sharp edge', capeties 'stack', deserties 'desert', granicies 'border', arguties 'joke', caducies 'damage', maneries 'sort, manner' and munities 'rampart' (Rzepiela 2000: 158). He found only one example (hapax legomenon) of an -ities derivative - crispities 'tortuosity'. The eLexicon of the Polish Medieval Latin gives the following-ities forms:

- amarities 'bitterness'

- avarities 'avarice'

- calvities 'baldness'

- canities 'grey hair'

- desertities 'desert'

- durities 'hardness'

- grossities 'thickness'

- immundities 'dirt'

- mollities 'softness'

- mundities 'cleanliness'

- munities 'rampart'

- perities 'experience'

- pigrities 'sloth'

- planities 'plain'

- polities 'cleansing'.

It is therefore advisable to postulate one more step in the derivational chain which Weysenhoff-Brożkowa (1991: 23) put forward - namely the reanalysis of the word granic-ia (changed from earlier granic- $a$ to conform with the Latin word-formation and phonotactics and avoid the pronunciation of /-ika) as the -itia formation - granicia - thus enabling both the creation of the variant granic-ies (-ies form) and the reanalysis of it as gran-icies (-ities form). This type of inflection of the Latin fifth declension, despite being unproductive, is still used in forms ending with -ia and -itia providing at least the potential of forming the -ies and -ities variants. The fact that granicia could be analyzed on a synchronic level by users of medieval Latin in Poland both as an -ia and-itia derivative probably explains why its counterpart formation in -(it)ies was ultimately created and became used very frequently thereafter. Granicies is also more distinct from its Polish original word granica than the Latin granicia. 


\section{REFERENCES}

du Cange = du Cange et al., 1883-1887, Glossarium medice et infimce latinitatis, Niort, [on-line] http://ducange.enc.sorbonne.fr/.

Elexicon = Elektroniczny Stownik Łaciny Średniowiecznej $w$ Polsce, [on-line] http://scriptores.pl/elexicon/.

Klingenschmitt G., 1992, „Die lateinische Nominalflexion“, [in:] Panagl O., Krisch T., 1992, pp. 89-135.

Panagl O., Krisch T., 1992, Latein und Indogermanisch, Innsbruck.

Pedersen H., 1926, La cinquième déclinaison latine, Copenhagen.

Rzepiela M., 2000, Derywacja sufiksalna $w$ tacinie średniowiecznej - rzeczownik, [unpublished Ph.D. dissertation], Kraków.

Schrijver P., 1991, The Reflexes of the Proto-Indo-European Laryngeals in Latin, Amsterdam - Atlanta.

Sławski F., 1952-1982, Stownik etymologiczny języka polskiego, Kraków.

Stownik Staropolski = Urbańczyk S. (ed.), 1954-2002, Stownik staropolski, Kraków.

Weiss M., 2009, Outline of the Historical and Comparative Grammar of Latin, Ann Arbor.

Weysenhoff-Brożkowa K., 1991, Wptyw polszczyzny na łacinę średniowieczna $w$ Polsce, Kraków. 